\title{
2016-2017 APSA Congressional Fellowship Program Office Placements
}

$\mathrm{F}$ ounded in 1953, the APSA Congressional Fellowship Program is the nation's oldest and most prestigious congressional fellowship. More than sixty years later, the program remains devoted to its original objective of expanding knowledge and awareness of Congress. For nine months, select political scientists, journalists, doctors, federal executives, and international scholars gain "hands on" understanding of the legislative process by serving on congressional staffs. Through this unique opportunity, the association enhances public understanding of policy-making and improves the quality of scholarship, teaching, and reporting on American national politics. For more information about the program visit www.apsanet.org/cfp. The placements for 2016-2017 are listed below.

\section{HOUSE}

\section{Robert Ahern}

Rep. Earl Blumenauer (D-OR)

Masatoshi Asaoka

Rep. Ami Bera (D-CA)

Gabrielle Bardall

Rep. Jan Schakowsky (D-IL)

Alex Garlick

Rep. Joe Kennedy III (D-MA)

Christine Gleason

Rep. Nancy Pelosi (D-CA)

Josephine Nguyen

Rep. Kevin Brady (R-TX)

Tracy Thomas

Rep. Jeff Fortenberry (R-NE)

SENATE

Peter Curran

Sen. Dianne Feinstein (D-CA)

Julia Driessen

Sen. Brian Schatz (D-HI)

Elena Elkin

Sen. Sheldon Whitehouse (D-RI)

Christopher Friese

Sen. Robert P. Casey (D-PA)

Jeremy Gelman

Sen. Jack Reed (D-RI)

Punam Ohri-Vachaspati

Sen. Kirsten Gillibrand (D-NY)

Susie Nanney

Sen. Amy Klobuchar (D-MN)
Katie Wright

Sen. Al Franken (D-MN)

Emily Zehner

Sen. Jeff Flake (R-AZ)

\section{COMMITTEES}

Daryll Dykes

House Subcommittee on Health, Energy and Commerce Committee (Majority)

Kathryn Haake

Senate Finance Committee (Minority)

Brian Kaskie

Senate Special Committee on Aging (Majority)

\section{Chris Kindelan}

House Committee on Oversight and Government Reform (Majority)

Kimberly Lehn

House Armed Services Committee (Majority)

\section{Michael Parrott}

House Committee on Natural Resources (Minority)

\section{Daniel Ochylski}

House Subcommittee on Health, Committee on Ways and Means (Minority)

\section{Anne Ordway}

Senate Committee on Health, Education, Labor, and Pensions (Minority)

\section{EXECUTIVE BRANCH AND OTHER PLACEMENTS}

\section{Amanda Borer}

Health Resources and Services Administration
Pamela Cacchione

Center for Medicaid and Medicare Services

JaNeen Cross

National Association of Social Workers

Annette DeVito Dabbs

Department of Health and Human Services, Office of the National Coordinator, Office of Care Transformation

Julia Driessen

Center for Medicaid and Medicare Services

Gary Epstein-Lubow

Center for Clinical Standards and Quality, Center for Medicare and Medicaid Services

\section{Sharon Inouye}

Centers for Medicare and Medicaid Services

\section{Fazal Khan}

Agency for Healthcare Research and Quality, Department of Health and Human Services

Madeline Naegle

Pan American Health Organization

Lynn Reinke

Altarum Institute

Gary Stein

Coalition to Transform Advanced Care and the American Bar Association Commission on Law and Aging

\section{Turner West}

Office of the Surgeon General and Altarum Institute. 